\title{
Örgütsel Bağlılığın Oluşmasında Kadın Akademisyenlerin Rolünün Nitel Araştırma Yöntemiyle Belirlenmesi: KTMÜ Örneği \\ (Determining The Role of Women Academians in the Formation Establishment of Organizational Commitment with Qualitative Research Method: The Case of KTMU)
}

\author{
Erkan AKGÖZ iD a Simge ŞALVARCI iD b Nurzat NURLANOVA iD c \\ a Kırgızistan-Türkiye Manas Üniversitesi, Bişkek, Kırgızistan. eakgoz@hotmail.com \\ bSelçuk Üniversitesi, Konya, Türkiye. simge tokay@hotmail.com \\ cKırgızistan-Türkiye Manas Üniversitesi, Bişkek, Kırgızistan. nuri.0405.70@gmail.com
}

\begin{tabular}{|c|c|}
\hline MAKALE BİLGİSİ & ÖZET \\
\hline $\begin{array}{l}\text { Anahtar Kelimeler: } \\
\text { Örgüt } \\
\text { Örgütsel Bağlılık } \\
\text { Kadın Akademisyen }\end{array}$ & $\begin{array}{l}\text { Amaç - Kadınların iş ve sosyal hayatta daha fazla yer alması, cinsiyete yönelik akademik } \\
\text { çalışmaların yoğunlaşmasına neden olmuştur. Farklı disiplinler tarafından yapilan araştırmaların } \\
\text { büyük bir çoğunluğu kadınların iş hayatında karşılaştıkları engeller üzerine yoğunlaşmıştır. } \\
\text { Kadınların çalıştığı kuruma olan bağlılığı ve bunun oluşmasındaki rolü üzerine araştırmalar ise } \\
\text { sınırlı düzeydedir. Bundan dolayı çalışmanın temel amacı, örgütsel bağlllığın oluşmasında kadın } \\
\text { akademisyenlerin rolünü tespit etmek ve aralarındaki ilişkiyi incelemektir. }\end{array}$ \\
\hline $\begin{array}{l}\text { Gönderilme Tarihi } 4 \text { Eylül } \\
2019 \\
\text { Revizyon Tarihi } 12 \text { Kasım } 2019\end{array}$ & $\begin{array}{l}\text { Yöntem - Çalışmada öncelikle örgüt ve örgütsel bağlllık konuları açıklanmış, sonrasında ise kadın } \\
\text { akademisyenlerin durumu ve örgütteki rolünden söz edilmiştir. Araştırma için ilgili literatürden } \\
\text { yararlanılarak yapılandırılmış mülakat tekniğine uygun soru formları hazırlanmıştır. Bu sorular } \\
\text { yardımıyla çalışma için gerekli olan veriler Kırgızistan-Türkiye Manas Üniversitesi'ndeki kadın } \\
\text { akademisyenlerden elde edilmiştir. }\end{array}$ \\
\hline $\begin{array}{l}\text { Makale Kategorisi: } \\
\text { Araştırma Makalesi }\end{array}$ & $\begin{array}{l}\text { Bulgular - Araştırma kapsamında } 16 \text { kadın akademisyen ile görüşme gerçekleştirilmiştir. } \\
\text { Katılımcıların büyük bir kısmı (\% 68,75) } 10 \text { yıldan fazla akademisyen olarak görev yaptıkları } \\
\text { belirlenmiştir. Evli (\% 87,50) akademisyenlerin çoğunlukta olduğu katılımcların genel olarak } \\
\text { örgütsel bağlllık duygusuna sahip oldukları tespit edilmiştir. Ancak bunların büyük bir bölümü } \\
\text { örgütsel bağlılığın oluşmasında kendi rollerinin olmadığını da belirtmektedirler. Bununla birlikte } \\
\text { kadın akademisyenlerin meslektaşları ve çalıştıkları kurumla bağlllıklarının olumlu olduğu } \\
\text { sonucuna da ulaşılmıştır. }\end{array}$ \\
\hline & $\begin{array}{l}\text { Tartışma - Araştırma sonucunda kadınların iş hayatında yer almaları büyük bir mücadele } \\
\text { sonucunda elde edildiği görülmüştür. Dünya genelinde bazı bölümlere kadınların alınmadı̆̆ı, bazı } \\
\text { yerlerde ise kadınların çalışmasının yasak olduğu da görülmektedir. Ayrıca kurumlarda kadınlara } \\
\text { yönelik herhangi yazılı bir kural veya politika da bulunmamaktadır. Tüm bu olumsuzluklara } \\
\text { rağmen örgütsel bağlılığın oluşmasını olumlu yönde etkilemektedirler. }\end{array}$ \\
\hline
\end{tabular}

\begin{tabular}{l}
\hline ARTICLE INFO \\
\hline Keywords: \\
Organization \\
Organizational Commitment \\
Woman Academician
\end{tabular}

Received 4 September 2019 Revised 12 November 2019 Accepted 15 November 2019

Article Classification: Research Article

\section{ABSTRACT}

Purpose - Women's involvement in work and social life has led academic studies to concentrate on gender. The vast majority of research conducted by different disciplines focuses on the barriers women face in business. Research on women's commitment to the institution and its role in its formation is limited. Therefore, the main purpose of the study is to determine the role of woman academicians in the formation of organizational commitment and to examine the relationship between them.

Design/methodology/approach - In the study, firstly, organizational and organizational commitment issues were explained separately and then the situation of woman academicians and their role in the organization were mentioned. Questionnaires were prepared according to the structured interview technique by using the relevant literature. With the help of the questions, the data required for the study were obtained from woman academicians in the Kyrgyzstan-Turkey Manas University.

Findings: Interviews were conducted with 16 female academicians. Most of the participants $(68,75 \%)$ were found to be academicians for more than 10 years. Married $(87,50 \%)$ participants were found to be predominant and to have a general sense of organizational commitment. However, most of them state that they do not have their own role in the formation of organizational commitment. 
In addition, it has been concluded that woman academicians have positive loyalty with their colleagues and the institution they work for.

Discussion - As a result of the research, it was seen that the participation of women in business life was obtained as a result of a great struggle. It is also seen that some parts of the world do not accept women, and in some places it is forbidden for women to work. In addition, there are no written rules or policies for women in institutions. Despite all these negativities, women positively affect the formation of organizational commitment.

\section{GİRIŞ}

Örgüt, birtakım amaçlar doğrultusunda bireylerin çabalarının koordine edildiği yönetimsel bir işlev olarak tanımlanmaktadır. Bağlılık ise bireyler ile ait oldukları kuruma karşı hissedilen güçlü duyguları ifade etmektedir. Bu anlamda örgütsel bağllık; bireyin görev yaptığı işletmenin amaçlarına ve değerlerine olan inancını, bu amaçları gerçekleştirebilmesi için çabalama arzusunu, örgütte kalmaya karşı duyduğu istek olarak kabul edilmektedir. Örgütler için özellikle yetenekli personeli çekmek ve onları örgütte tutabilmek büyük önem arz etmektedir. Bundan dolayı örgütsel bağlllık kavramı her geçen gün daha fazla önem kazanarak işletmeler için bir yönetim uygulaması haline geldiği görülmektedir. Çünkü örgütsel bağlılığı üst seviyede olan personel daha fazla performans gösterir ve işten ayrılma isteği azalır. Bundan dolayı son yıllarda başta ABD olmak üzere birçok yerde örgütsel bağlllık ile ilgili çalışmaların ağırlıkta olduğu görülmektedir. Bu çalışmalara göre kadınların daha duygusal olmaları ve örgütsel bağlılık duygusunun daha fazla önem verdikleri anlaşılmaktadır.

Akademisyenlik sadece mesai saatleri içerisinde eğitim kurumlarında yapılan çalışmalar ile yürütülecek kadar kolay bir meslek değildir. Çalışma saatleri dışında da yoğun bir çaba gerektirir. Erkekler bu tür çalışmalarını rahat bir şekilde yerine getirirken, kadınlar bir takım zorluklarla karşılaşmaktadırlar. Çünkü kadınların geleneksel ev işlerini yapmak, çocuk bakmak, eş olmak vb. birçok sorumlulukları bulunmaktadır. Ayrıca kadınlar çalışma hayatında amirleri veya mesai arkadaşları tarafından da bir takım haksız uygulamalara maruz kalabilmektedirler. Bundan dolayı hazırlanan bu çalışmada öncelikle örgüt ve örgütsel bağlılık kavramları açıklanmış, daha sonra kadın akademisyenlerin durumu ve örgütteki rolü tespit edilmeye çalışılmıştır.

\section{KAVRAMSAL ÇERÇEVE}

\section{1. Örgütsel Bağlılık Kavramı}

İnsan, örgütlerin değişmeyen üretim faktörleri arasında yer almaktadır. 2000'li yıllar teknoloji çağı olarak adlandırılsa da, örgütlerin varlı̆̆ını sürdürebilmesi ve mevcut teknolojik gelişmelerden yararlanabilmesi için insana gereksinim duyulmaktadır. Örgütün hedeflerine yönelik faaliyetlerinin sürdürülebilir olabilmesi için en temel konulardan biri, çalışanların işe devamlılıklarını sağlamaktır. Örgütte çalışan devir hızının yüksek olması, maddi kayıplara sebep olmakla beraber çalışanların motivasyonun zayıflamasına, dolayısıyla da üretim kalitesinin düşmesine yol açmaktadır. Bundan dolayı işletmelerde iş gücü devir oranı nedeniyle ortaya çıkan olumsuzlukların giderilmesinde önemli bir unsur olarak kabul edilen örgütsel bağlllık; personelin çalıştı̆̆ kuruma bağlanarak kurumunu önemsemesi yönündeki tutumu ya da davranışıdır. Örgütsel bağlılık; örgütün amaçlarına ve değerlerine karşı güçlü bir güven hissi duyarak bu amaç ve değerlerin kabul edilmesi, örgüt yararına en yüksek düzeyde çaba harcama ve örgütte kalmak için güçlü bir istekliliktir (Gü̈clü, 2006).

Örgütsel bağlılık, çalışanların işletmenin hedeflerine ulaşmasına yardımcı olma taahhüdünde bulunma durumudur ve çalışanların tanımlanma, katılım ve sadakat seviyelerini içermektedir. Ayrıca bireylerin davranışları, inançları ve tutumlarıyla ölçülebilen ve çok düşükten çok yüksek bir yere kadar değişebilen duygusal bir tepkidir (Zefeiti and Mohamad, 2017). Örgütsel bağlllık, bireyin kurum ile özdeşleşmesinin ve katılımının gücüdür. Bu tür bir taahhüdün bileşenleri, kuruluşun amaç ve değerlerine inanma ve benimseme, kurumun yararı için fazladan çaba göstermeye istekli olma ve kurumsal bağlllığı devam ettirme arzusu olarak da tanımlanmaktadır. Başka bir deyişle, örgütsel bağlılık, çalışanın örgütsel amaç ve değerlere olan inancı, bunların aynı şekilde benimsenmesi, örgütsel amaçlara ilave çaba gösterme arzusu ve örgütün bir üyesi olarak kalmak için güçlü bir dilektir (Bişgin, 2014).

İş görenlerin kurumsal aidiyet duygusunu gösteren ve psikolojik bir durum olan örgütsel bağlllık; örgütsel davranış ve örgütsel psikoloji alanında oldukça sık incelenen bir konudur. Son yıllarda örgütsel bağlllığın bu denli önemli hale gelmesindeki en önemli husus "insan" unsurudur. Her insanın farklı derecede olmak üzere değişik ihtiyaçları bulunmaktadır. Ayrıca, çalışanların iş ortamında duygu ve düşünceleri doğrultusunda 
hareket etmesi insan yönetimini daha zor kılmaktadır. Bir çalışan, ihtiyaçları karşılandığında veya kendini mutlu hissettiği sürece örgütte çalışmaya devam eder ve örgütsel bağlılığını sürdürür. Fakat iş görenin çalıştığı örgütün amaç ve değerlerini benimsemesi ve örgüte bağlllı̆̆ı değişkenlik gösterebilir. Bundan dolayı örgütsel bağlılık kurumlar açısından önem kazanmakta, insan kaynakları yönetimini stratejik bir konuma getirmektedir.

Örgütsel bağlılık konusunda yapılan çalışmalara en önemli katkıyı Allen ve Meyer yapmıştır. Allen ve Meyer'e göre örgütsel bağlılık; "bireyi örgüte bağlayan psikolojik bir durum"dur. Bundan dolayı örgütsel bağlılık; duygusal, devam ve normatif bağlılık bileşenlerinden oluşmaktadır (Meyer \& Allen, 1997).

\subsubsection{Duygusal Bağlılık}

Duygusal bağllık, işletmede çalışanların duygusal olarak kendi istekleriyle işletmede kalma arzusunu ifade etmektedir. Duygusal bağlllıkla en tutarlı davranış, iş deneyimleriyle ilişkilendirilmektedir. Çalışanlar, örgütte temel ihtiyaçlarını karşılamaktan ziyade daha yüksek bir duygusal bağlılık oluşturmalarını sağlayacak deneyimler ister. Çünkü duygusal bağlılığı gelişmiş olan çalışanlar, kendilerini örgüte adayan sadık çalışanlardır. Duygusal bağlılık düzeyleri güçlü olan çalışanlar, mecburiyetten değil, kendileri istediği için örgütte çalışmaya devam ederler (Bozkurt ve Yurt, 2013).

\subsubsection{Devam Bağlılığı}

Devam bağllığı, işten ayrılmanın getireceği maliyetlerin bilincinde olan çalışanların, kurumdaki görevlerini sürdürmeleri şeklinde tanımlanmaktadır. Kişinin örgütte kalma arzusu, örgütteki yatırımlarının toplamından az olması, örgütten ayrıldığında kaybedecekleri ve alternatiflerinin sınırlı olması ile paraleldir. Çalışanın işletmedeki kıdemi ve faydası, işten ayrılmanın maliyetinden fazla ise çalışan o kuruma bağlanır. Böylesi bir bağlılık gerçek bir bağlılık olarak kabul edilmektedir. Devam bağlılığının oluşmasını sağlayan bir takım bireysel ve örgütsel faktörler bulunmaktadır. Bunlar çalışanların yeteneği, eğitimi, terfi olanakları, bireysel yatırımları, emeklilik primi ve toplum gibi unsurlara göre farklılık göstermektedir (Bozkurt ve Yurt, 2013).

\subsubsection{Normatif Bağlılık}

Meyer ve Allen 1990 yılında duygusal ve devam bağlılı̆̆ına ilave olarak Weiner ve Vardi'nin önerdiği ve Weiner tarafından geliştirilen "normatif" veya "ahlaki" boyutunu da ekleyerek üç boyutlu bir örgütsel bağlllık modeli ortaya koymuşlardır. Normatif bağlılık, çalışanların örgütlerine karşı duydukları sorumluluklarını ifade etmektedir. Kuralcı bağlılık olarak da kabul edilen normatif bağlılık; örgütsel bağlılı̆̆ın sorumluluk ve ahlaki boyutunu oluşturmaktadır. Çalışanların örgütte kalmayı sürdürmeye yönelik sorumluluk bilincini yansıtmaktadır. Kişinin kurumuna bağlılığı sosyal sorumluluk bilincine sahip olması, örgütte kalmayı bir görev olarak algılaması ile ilişkilendirilir. Bireyin, örgütte kalmanın uygun olacağını düşünmesi sonucu ortaya çıkarak diğer iki çeşit bağlllıktan farklı özellik göstermektedir. Güçlü bir normatif bağlllık duygusuna sahip personelin örgütsel bağlllık duygusu daha yüksektir. Çünkü bağlılık hissi, çalışanların yaptıklarının etik ve doğru olduğuna inanmaları sonucunda belirli davranışlar sergilemelerine sebep olmaktadır (Doğan ve Kılıç, 2007).

Çalışanların örgütsel bağlllıkları, kurumların üretim maliyetlerini düşürmekte; kârlılıklarını ve performanslarını artırmakta; tüm süreçleri iyileştirmekte ve kurumsal imajı güçlendirmektedir. Yapılan çalışmalar personel bağlılığının, güveni, güvenin de verimliliği arttırdığını ortaya koymaktadır. İş görenlerin örgütün amaçlarını, değerlerini, inançlarını kabul etmeleri ve çalıştıkları örgütle uyumlu olmaları, örgütün işleyişi ve yönetimin aldığı kararların uygulanması konularında faydalar sağlamaktadır. Bunun yanı sıra, çalışanların örgüte sosyal uyumu da sağlanarak hem çalışan hem de işveren açısından örgütün sürdürülebilirliğine olumlu katkı yapmaktadır (Ünlü, 2017).

\subsection{Kadın Akademisyenlerin Örgütteki Rolü}

Kadınların iş hayatındaki konumu, sosyolojiden psikolojiye, işletmeden eğitime birçok alanda pek çok çalışmaya konu olmuştur. Farklı disiplinler tarafından yapılan araştırmalarda genel olarak kadın çalışanların iş hayatında karşılaştıkları engeller ile olumlu ve olumsuz ayrımcılıklar gibi sorunlar ele alınmıştır. Bu araştırmaların ortak özelliği, kadınların iş yaşamında genel olarak olumsuzluklarla karşılaştıkları ve bunların yıllardır devam ettiğidir (Yıldız, 2018).

Birçok alanda olduğu gibi akademik alanda da kadınların istihdamı oldukça zor şartlarda gerçekleşmektedir. Üniversitelerde kadınların öğrenci veya akademisyen olarak görev almaları büyük bir mücadele sonucunda hak edilmiştir. Buna rağmen kadınların sadece belirli bölümlere alındığı, yükseköğretim seviyesinde karma 
eğitimin yasak olduğu uygulamaların dünyanın farklı bölgelerinde halen devam ettiği de görülmektedir (Şentürk, 2015). Ayrıca akademisyenliğin temel görevlerini yerine getirmeye gayret eden, aynı zamanda günlük ev işlerini, annelik ve eş olma gibi genel sorumlulukları da bulunmaktadır. Bu sorumluluklar, kadın akademisyenlerin iş hayatında birçok sorunla karşı karşıya kalmalarına neden olmaktadır. Kadın akademisyenler araştırmacı, öğretici, meslektaş, anne, eş, arkadaş gibi görevlerinden dolayı çoğu zaman bireysel ihtiyaçlarından ve kişisel zamanlarından vazgeçmek zorundadır (Dikmen \& Maden, 2012). Tüm bu olumsuzluklarla birlikte kadın akademisyenler yükseköğretimde erkeklerle eşit temsil oranına sahip değildirler. Bu durum yükseköğretimde cinsiyet ayrımcilı̆ının bir göstergesi olarak kabul edilmektedir (Yildiz, 2018).

Kadın akademisyenlere yönelik yapılan araştırmalar, kadın akademisyenlerin sahip olduğu çoklu roller, birçok işi aynı anda yapmak zorunda olmaları, akademik çalışmalarını olumsuz yönde etkilediğini göstermektedir. Akademik ve idari kadroda yer alan kadınlar ve kadın yöneticilere yönelik yapılan bir çalışma, kadınların ev-aile yaşamı ile akademik ortamda karşılaştıkları toplumsal cinsiyet temelli birtakım zorluklardan dolayı üst düzey yönetim kademelerde görev alamadıklarını ortaya koymaktadır (Suğur ve Cangöz, 2016).

Akademik camiada kadın akademisyenin sayısı her geçen gün biraz daha artmaktadır. Ancak bu artış yönetim kademesine aynı oranda yansımamaktadır (Kalkın vd., 2015). Kadınların yönetim birimlerinde eşit derecede görev alabilmeleri için uzun bir süre beklemeleri gerekmektedir (Korkmaz, 2016). Farklı sektörler incelendiğinde de kadınların yönetim kademesinde yeterli düzeyde görev almadıkları görülmektedir. Kadınların yönetim kademesinde az olmasına yönelik yaklaşımlar, toplumsal rol ve cinsiyet ayrımcılığından kaynaklanmaktadır. Kadının aile içi sorumluluğu ile toplumdaki cinsiyet rollerine ilişkin kültürel yargılar, kadınların üst düzey kademelerde görev almalarına engel teşkil etmektedir. Kadınların yönetici olmalarındaki engeller "pipeline" ve "cam tavan" yaklaşımı ile açıklanmaktadır. Pipeline; kadınların erkeklerle aynı eğitim düzeyine sahip olsalar dahi erkekler kadar başarılı olamayacakları fikridir. Cam tavan ise; kadınların üst düzey yönetim kademesine ulaşmasının önündeki görünmez engelleri ifade etmektedir (Klenke, 2011; Suğur ve Cangöz, 2016; Gökdeniz vd., 2015; Liou, 2008)..

Yıldız (2018) tarafından yapılan araştırma sonuçları, kadınların erkek akademisyenlere oranla mesleki anlamda daha fazla doyum elde ettiğini, akademisyenliğin işlevlerine yönelik erkek akademisyenlerin olumsuz, kadın akademisyenlerin ise olumlu bir algıya sahip olduğunu ortaya koymaktadır. Kadın akademisyenlerin erkek akademisyenlere oranla daha fazla sorunla karşılaşmalarına rağmen, erkek akademisyenlere göre yaptıkları işten daha fazla doyum elde ettikleri de anlaşılmaktadır. Bu durum kadın akademisyenlerin mesleklerini daha çok sevdiklerini göstermektedir (Yıldız, 2018).

\section{ARAŞTIRMANIN YÖNTEMI}

Kadın akademisyenlerin örgütsel bağlılıklarını belirlemek için hazırlanan bu çalışma, aşağıda belirtilen metodolojiye göre sonuçlanmıştır.

Tüm akademisyenlerin temel görevi eğitim öğretim faaliyetlerini yürütmek, bununla birlikte bilimsel araştırmalar yapmaktır. Bu iki görev de son derece dikkat ve emek isteyen işlerdir. Çalışma ortamında mutsuz olan akademisyenlerde dikkat, verimlilik ve performans düşer. Bu yüzden akademisyenlerin, kurumlarında yaşadıkları sorunların araştııılması örgütsel ve toplumsal açıdan oldukça önemlidir.

Ayrıca örgütler için yetenekli çalışanları işe almak kadar bunları örgütte tutabilmek daha da önemlidir. Yetenekli çalışanların gelişmesine katkıda bulunmak ve bunun sonucunda onların kurumlarına bağlı kalmalarını sağlamak büyük önem arz etmektedir. Akademisyenler eğitimci kimlikleri ile yeni nesillerin davranışlarına ve vizyonlarına etki eden bireylerdir. Bu yüzden bu çalışma gelecek nesilleri yetişmesinde büyük katkısı olan kadın akademisyenler üzerine yapılmıştır.

Hazırlanan bu çalışma tüm akademik birimlerde görev yapan kadın akademik personeli kapsamaktadır. Araştırma kapsamında farklı bölgelerde faaliyet gösteren kurumlardaki kadın akademisyenlere ulaşmak mümkün olmadığından KTMÜ’de görev yapan kadın akademisyenler araştırma evreni olarak belirlenmiştir. Nitel araştırmalarda örneklem büyüklüğünün en az 15 kişi olması önerilmektedir (Mason, 2010). Bu yüzden araştırma 1995'te kurulan Kırgızistan-Türkiye Manas Üniversitesi'nde görev yapan 16 kadın akademik personel ile Mart 2019 tarihinde görüşme gerçekleştirilmiştir. 
Kadın akademisyenlerin örgütsel bağlılığın oluşmasındaki rolünü belirlemek için hazırlanan bu çalışmada nitel araştırma yöntemlerinden mülakat (görüşme) tekniği kullanılmıştır. Kozak (2014) mülakat için kullanılacak soru formu, mevcut literatür taraması yapıldıktan sonra araştırmanın amacına uygun olarak oluşturulması gerektiğini belirtmektedir. Bundan dolayı araştırmada öncelikle ilgili alan yazın titizlikle taranmış ve araştırmanın amacına uygun soru formu hazırlanmıştır. Soruların araştırmanın amacına uygun olup olmadığını belirlemek için alanında uzman kişiler tarafından incelenmiş ve soru formuna son şekli verilmiştir.

Soru formu toplam 14 sorudan oluşmaktadır. Katılımcıyı görüşmeye hazırlamak ve ilgi duymasını sağlamak adına, soru formunun ilk bölümünde demografik ve çalışma süresi ile ilgili bilgileri öğrenmeye yönelik 5 soruya yer verilmiştir. Kalan 9 soru ise, kadın akademisyenlerin örgütsel bağlılığın oluşmasındaki rolünü değerlendirmeye yöneliktir. Görüşme öncesinde katılımcılara kimlik bilgilerinin gizli kalacağına dair söz verilerek araştırma sonuçlarının daha objektif olması amaçlanmışır. Görüşmeler sırasında notlar alınmıştır. Alınan notlar bilgisayar ortamına aktarıldıktan sonra Microsoft Excel programı yardımıyla değerlendirilerek içerik analizine tabi tutulmuştur.

\section{ARAŞTIRMANIN BULGULARI}

Kadın akademisyenlerin örgütsel bağlılıkla ilgili düşüncelerini belirlemek için yapılan nitel araştırma sonucu elde edilen bulgular aşağıda yer almaktadır.

\subsection{Demografik Bulgular}

Araştırma kapsamında yer alan katılımcılara ait bulguları yorumlamak için öncelikle demografik analizler yapılmıştır. Yapılan analiz sonucuna göre Tablo 1 hazırlanmıştır. Buna göre katılımcıların yarısı (8 kişi) 35-40 yaş grubunda yer almaktadır. Araştırma kapsamında yer alan akademisyenlerin sadece \% $18,75^{\prime} \mathrm{i} 35$ yaşından daha küçük yaş grubundadırlar. Kadın akademisyenlerin büyük bir bölümünün $(\%$ 81,25) şu an çalışmış oldukları kurumda 10 yıldan fazla süredir çalıştıkları görülmektedir. Katılımcıların \% 37,50'sinin 15-19 yıldır akademisyenlik yaptıkları da anlaşılmaktadır. Akademisyenlerin \% 87,50'si evli, \% 12,25'i ise bekârlardan oluşmaktadır. Katılımcıların demografik özellikleri ile ilgili diğer bilgiler ise Tablo 1'de görülmektedir.

Tablo 1: Akademisyenlere İlişkin Demografik Bilgiler

\begin{tabular}{|c|c|c|c|}
\hline & & Say1 & Yüzde \\
\hline \multirow{3}{*}{ Yaş } & $30-34$ & 3 & 18,75 \\
\hline & $35-40$ & 8 & 50,00 \\
\hline & 40 üstü & 5 & 31,25 \\
\hline \multirow{2}{*}{ Medeni durum } & Evli & 14 & 87,50 \\
\hline & Bekâr & 2 & 12,50 \\
\hline \multirow{5}{*}{$\begin{array}{l}\text { Akademik } \\
\text { ünvan }\end{array}$} & Prof. Dr. & 1 & 6,25 \\
\hline & Yrd. Doç. Dr. & 4 & 25,00 \\
\hline & Öğr. Gör. Dr. & 4 & 25,00 \\
\hline & Öğr. Gör. & 6 & 37,50 \\
\hline & Arş. Gör. & 1 & 6,25 \\
\hline \multirow{4}{*}{$\begin{array}{l}\text { Bu kurumda } \\
\text { çalışma süresi }\end{array}$} & 5 yildan az & 2 & 12,50 \\
\hline & $5-9$ & 1 & 6,25 \\
\hline & $10-14$ & 5 & 31,25 \\
\hline & $15-19$ & 8 & 50,00 \\
\hline \multirow{6}{*}{$\begin{array}{l}\text { Akademisyenlik } \\
\text { deneyim süresi }\end{array}$} & 5 yildan az & 2 & 12,50 \\
\hline & $5-9$ & 1 & 6,25 \\
\hline & $10-14$ & 5 & 31,25 \\
\hline & $15-19$ & 6 & 37,50 \\
\hline & $20-24$ & 1 & 6,25 \\
\hline & 25 yıl ve daha fazla & 1 & 6,25 \\
\hline
\end{tabular}


E. Akgöz - S. Şalvarcı - N. Nurlanova 11/4 (2019) 2612-2621

\subsection{Kurumun Kadın Akademisyenlere Yönelik Politika ve Kurallar ile İlgili Bulgular}

Araştırmanın bu bölümünde kadın akademisyenlere çalışma hayatında kurumun desteğini araştırmak için "Kurumun kadın çalışanlara yönelik politika ve kuralları var mı?" sorusu yöneltilmiştir. Katılımcıların verdikleri cevaplara göre yöneticilerin ve/veya kurumun kadınlara yönelik uyguladıkları politikalara ilişkin sonuçlar aşağıda yer almaktadır. Bu sonuçlara göre kurumda kadınlara yönelik hiçbir yazılı kural ve politikanın olmadığı tespit edilmiştir.

Bu konuda kadın akademisyenler şu sözleri ifade etmişlerdir:

"Bize yönelik kural veya politika olduğunu sanmıyorum. Kadın ve erkekler aynı şartlar altında çalışmaktadırlar. Kadınlar için doğum izni var. O kadar." (A11)

"Her hangi özel bir uygulama yok. Sadece doğum izni var. Bu da genel bir uygulamadır." (A5)

Kurumun kadın akademisyenlerin sosyalleşmelerine yönelik çalışmaları destekleyip desteklemediğini belirlemek için de "Meslektaşlarınızla sosyalleşmeniz kurum tarafından destekleniyor mu?" sorusu sorulmuştur. Bu soruya kadın akademisyenler farklı cevaplar vermişlerdir. Konuya dair ifadeler aşağıda yer almaktadır:

"Meslektaşlarımla sosyalleşmem kurum tarafindan destekleniyor. Kariyer konusunda kurum beni desteklemeye odakl değil, ama karşı da değil tabii ki." (A2)

"Çalışı̆̆ım kurumda kadınlara yönelik hiçbir özel uygulama yok, ama sosyalleşmemiz için de herhangi bir kısıtlama bulunmamaktadır" (A16)

"Sosyalleşmemizi destekliyor, ama çok değil. Daha çok işe odaklı olmamızı istiyorlar." (A8)

"Zaten bir kurumda çalışıp da sosyalleşmemek mümkün değildir. Meslektaşlarım artık en iyi dostlarımdır." (A9)

$\mathrm{Bu}$ ifadelerin ışığında, kurumda kadın akademisyenlere yönelik hiçbir yazılı politikanın olmadı̆̆ı ve kadınların sosyal anlamda kurum tarafından istenilen düzeyde olmasa da desteklendiği görülmektedir.

\subsection{Kariyer ile Örgütsel Bağlılık Arasındaki İlişkiye Yönelik Bulgular}

Araştırma kapsamındaki kadın akademisyenlere örgütsel bağlllı̆̆ın kariyerlerini nasıl etkilediği de sorulmuştur. Katılımcıların çoğu bu soruya olumlu cevap vermiştir. Bu konuda alınan cevapların bazıları aşağıda belirtilmektedir:

"Kurumunu ve işini seviyorsan tabii ki de kariyer başarısı elde edersin. Bundan dolayı bence olumlu etkiler." (A5)

"Hem kadın hem erkek için örgütsel bağglllık kariyer başarısını olumlu bir şekilde etkiler. Kişi sevdiği kurumda sevdiği işi yapryorsa daha çok başarılı olur." (A9)

"Bence bu insanın kişiliğine ve amaçlarına göre değişir. Çünkü kişi gelecekte de bu kurumda çalısmayı ve yükselmeyi planliyorsa kurumun taleplerine göre kendisini geliştirir" (A12)

"Kendimi ait hissettiğim bir ortamda, toplumun kadına yüklediği sorumlulukların göz ardı edilmediği bir ortamda daha verimli ve mutlu çalışırım. Böyle bir durum devamında başarıyı getirir." (A8)

"Herkes kendi için ve kendi kariyeri için çalışır ve çabalar. Bu yüzden örgütsel bağlllık kariyer başarısını çok da etkilemez." (A6)

"Önceden yoktu, hatta ne gerek var diye engelleniyordu. Ancak son 5-6 yıldır destekleniyoruz, bunu da kurumun menfaati için desteklendiğini düșünüyorum. Bundan birkaç yıl akreditasyon almamız sıkıntıllyd. Hemen kurum amirleri bizim kariyer yapmamızı özel olarak desteklediler. Ayrıca akademik ünvanı olan kişiler ile aynı ortamda çalışmak ve ortak çalışmalar yapmak benim mesleğime ve kariyerime bakış açımı olumlu yönde etkilemektedir" (A14)

"Etkiler, çünkü örgütsel bağlllık duygusu olan akademisyenin özgüveni oldukça yüksektir. Dolayısıyla kariyer basamaklarını da başarılı bir şekilde tamamlar." (A4)

"Kişide örgütsel bağglllık duygusu varsa, daha çok sorumluluk alır, daha çok katkı sağlamaya çalışır. Gösterdiğgi bu çabalar meslektaşları tarafindan takdir edilir ve onlar da yardımda bulunurlar. Örgütsel bağhllık ve kariyer başarısı arasında büyük bir ilişki vardır." (A1) 
E. Akgöz - S. Şalvarcı - N. Nurlanova 11/4 (2019) 2612-2621

Katılımcılar kurum ile örgütlerin kariyer planlarının birbirlerine paralel olduğunu belirtmektedirler. Kişiler başarılı olursa kurum da başarılı olur. Dolayısıyla her kurumun çalışanlarını sürekli motive etmeli ve kariyer planlamalarına yardımcı olmaları gerekmektedir.

\section{4. Örgütsel Bağlılığın Oluşmasına Kurum Amirinin Katkısına Ait Bulgular}

Amirin çalışanlara karşı tutumu örgütsel bağlılığı oluşturan önemli unsurlardandır. Bu nedenle, kadın akademisyenlere amirin örgütsel bağlllı̆̆ın oluşmasını nasıl etkilediğini belirlemek için "Sizce amirin tutumu örgütsel bağlılığının oluşmasını etkiler mi? Etkiliyorsa nasıl?" sorusu yöneltilmiştir. Bununla ilgili dile getirilen ifadeler aşağıda yer almaktadır:

“Evet. Amirin tutumu özgüven verir, tavrı ve konuşması ile örgütsel bağlllı̆̆ın oluşmasına olumlu katkı sağlar." (A1)

"Evet, onun işe olan tutumu ne kadar iyi ve yüksek ise, yanında çalışan personelin de öyle olur." (A7)

"Evet, etkiler. Amirin önderliğinde yapılan faaliyetler yanında çalışanları da doğrudan etkiler. Olumlu bir yönetimle çalışırsak kendimizi kuruma ait hissederiz. Bu da performansa yansır." (A8)

"Birlikte bir takım faaliyetler düzenliyor. Akşam yemeği, bayram yemekleri, doğum günü kutlamaları. Bunlar örgütsel bağhllı̆̆ın oluşmasını önemli yönde etkilemektedir." (A9)

"Özellikle rektörlük tarafından çok destekleniyoruz. Ancak bazen yöneticilerin bazı haksız davranışlarından dolayı moralimin bozulduğu hatta ağladığım durumlar da yaşadım." (A14)

"Eğer kurum amiri adil davranırsa bundan olumlu etkilenirim. Amirin adil davranması benim işime ve kurumuma bağlllı̆̆ımı artırır, işimi daha çok severek yaparım" (A12)

"Tabii ki. Amir takımın genel atmosferini belirler. Ĕ̆er amir çalışanları sürekli olarak teşvik ediyorsa, çalışanlar hep motive olurlar." (A10)

Katılımcıların vermiş olduğu cevaplara göre yönetim kademesinde bulunanlar örgütsel bağlllı̆̆ın oluşmasında önemli rol oynamaktadırlar. Amir pozisyonun da görev yapanlar öncelikle kendi sorumluluklarını yerine getirmeleri, sonra da tüm çalışanları kapsayacak faaliyetleri desteklemesi örgütsel bağlılık açısından büyük önem arz etmektedir.

\subsection{Kurum İklimine Yönelik Bulgular}

Çalışanların başarıya ulaşmasındaki en önemli unsur kurumdaki ılımlı ve dostane ortam ile amirlerin desteklemesi ve cesaretlendirmesidir (Özdevecioğlu, 2003). Araştırma esnasında katılımcılardan meslektaşları ile ilgili olumlu veya olumsuz olaylardan söz etmeleri rica edilmiştir. Araştırma kapsamında yer alan katılımcıların büyük çoğunluğu herhangi olumsuz bir durum yaşamadıklarını, genellikle olumlu olaylar yaşadıklarını ifade etmişlerdir. Katılımcıların bu soruya vermiş olduğu cevaplar şunlardır:

“Olumlu: İlk çalıştığım yillarda herhangi bir sorun olduğu zaman rektör beni hep desteklemişti ve kurum içinde elverişli bir atmosfer yaratirdi.

Olumsuz: Birkaç yıl önce meslektaşım ve bir öğrenci arasında olumsuz olay yaşanmışıtı. Eğitim sorununun etnik gruplar arası bir soruna dönüşmesi sonucu o meslektaşım artık burada çalışmaya devam edemedi." (A2)

"Olumlu: Takım olarak birlikte çalışabilmek. Bilimsel çalş̧malarda işbirliği yapmak çok güzel".

Olumsuz: Hata yaptığım zaman azarlanmıştım. Çalışanlara sürekli iş veriliyor. İşini erken bitirenlere daha çok iş verilir." (A9)

"Bu kurumda hiçbir arkadaşım veya amirim ile en ufak bir problem dahi yaşamadım" (A16)

"Olumlu: Danışman hocam beni hep desteklemiş ve motive etmişti.

Olumsuz: Ihanet ve kıskançlık yaşanmıştı. Sonucunda o insanla (meslektaşla) ilişkimi kestim. Konuşmuyorum."(A1)

“Olumlu: Mesai arkadaşlarımla genel olarak iyi ilişkilerim var. Kurumdaki tüm akademik ve idari personelin hepsiyle bir aile ortamında çalışıyoruz.

Olumsuz: Yönetim kademesinin özellikle müdürümüzün neden olduğu stres ve istekleri tüm çalışanların moralini bozuyor, hiç kimse kuruma gelmek istemiyor" (A12) 
E. Akgöz - S. Şalvarcı - N. Nurlanova 11/4 (2019) 2612-2621

"Ben bu kurumda direk olumlu veya olumsuz bir durum yaşamadım. Kim ne yaparsa kendine yapar" (A3)

"Bizim kurumda genellikle olumlu olur. Sadece amirler değil her zaman herkes birbirimizi desteklemeye çalışıyoruz." (A15).

"Genellikle olumlu şeyler yaşıyoruz. Özellikle ortak çalışmalarımızla birçok ziyaretimiz oldu, meslektaşlarımı daha yakından tanımama vesile oldu. Olumsuz olay çok az yaşadım. Şimdi hatırlamıyorum. Benim özelliğimden dolayı olumsuzlukları değil, iyilikleri hatırlıyorum" (A14)

Yukarıdaki cevaplar dikkate alındığında kurum ikliminin oluşmasında genel olarak bireysel özelliklerin ve beklentilerin etkili olduğu görülmektedir. Kurumlarda olumlu bir atmosferin oluşturulması için herkesin bireysellikten çok kurumsallığa önem vermesi gerekmektedir.

\subsection{Kurum ile Kadın Akademisyen Arasındaki İlişkiye Ait Bulgular}

Çalışanların örgütle arasında oluşan duygusal bağlılık, çalışanın örgüt ile bütünleşmesine katkı sağlamaktadır. Duygusal bağlılık, personelin örgütsel amaçları ve değerleri kabullenmesini, örgüt yararına daha fazla gayret göstermesini içermektedir (Yüceler, 2009). Duygusal bağlılığı gelişmiş çalışanlar kendisini tamamen örgüte adayan sadık personellerdir. Duygusal bağlılı̆̆ı sürekli ve güçlü olan çalışanlar, örgüt yararına işleri yaparken, bunları ihtiyaç duydukları için değil, kendi sorumluluk duygusuyla yapmaya devam ederler (Bozkurt ve Yurt, 2013). Bundan dolayı araştırma kapsamında yer alan katılımcılara kuruma karşı olan duygularını belirlemek amacıyla iki soru yöneltilmiştir. Bunlardan ilki "Sizce örgütsel băglılık kadın akademisyenin kariyer başarısını ne gibi etkilemektedir?" ikincisi ise; "Sizce çalıştığınız kurumda meslektaşlarınızın örgütsel bağlılı̆̆ıın oluşmasında sizin rolünüz var mı? Varsa nasıldır? Sorularıdır. Bu sorulara alınan cevaplardan bazıları şunlardır:

“Buranın mezunu, sonra da çalışanı olduğum için bağlılık duygum çok yüksek. Bazı işleri mesaiye kalıp, sıkıntısız yapıyorum. Öğrencilerle ders dışı görüşüyorum. Sosyal medyada kurumun sayfalarını takip eder ve olumsuz yorum veya haberlerle karşılaştığım zaman üzülürüm. Kendi varlı̆̆ımı ve kurum varlı̆̆ını paralel olarak görüyorum. Kesinlikle kendimi kurumun ayrılmaz bir parçası olarak görüyorum. Hayatımın büyük bir kısmı burada geçti."(A1)

"Kurumun amaçları ve değerleri benim için önemlidir. Başarılar çok sevindirir, özellikle birimler arasında yarışmalarda birinci olduğumuz zaman çok sevinirim." (A6)

"Kurumda oluşturduğumuz iyi ve güvenli ortam, her zaman farklı konularda birbirimize destek olmamızı să̆lıyor. Beraber yaptığımız faaliyetler kuruma olan bağlılığımızı daha da güçlendiriyor" (A13)

"Kendimi bu kurumun ayrılmaz bir parça olarak görmüyorum. Ben olmazsam da kurum kendi varlığını çok daha iyi bir şekilde devam ettirecektir." (A7)

"Görev yaptığım kurumun değer yargıları ve amaçları bence çok önemli, çünkü biz bir aileyiz. Bir hedefimiz var, kendi değgerlerim çalıştı̆̆ım kurumun değerleriyle örtüşüyor." (A15)

Kişiler genel olarak hem şimdi hem de gelecekte rahat bir hayat sürmek için çalışmaktadırlar. Çalıştıkları kurum personelin sadece mevcut durumunu değil, gelecekteki durumunu ekonomik ve sosyal açıdan etkilemektedir. Bundan dolayı kişi kendisine iyi bir kariyer imkânı sunan kuramlara daha fazla bağlı hisseder.

\section{7. Örgütsel Bağlılıkta Kadın Akademisyenlerin Rolüne Ait Bulgular}

Örgütsel bağlılığın oluşmasında kadın akademisyenlerin rolünü belirlemek için de sorular hazırlanmıştır. Bu amaç doğrultusunda katılımcılara "Çalıştı̆̆ınız kurumda meslektaşlarınızın örgütsel bağhlı̆̆ııın oluşmasında sizin rolünüz var mı? Varsa nasıldır?" sorusu yönetilmiştir. Bu soruya verilen cevapların birkaçı aşağıda yer almaktadır.

"Hiçbir fikrim yok. Örgütsel bağlılık birilerinin etkisi ile oluşmaz." (A11)

"Rolüm yok. Direk aklıma gelmiyor. Ama dolaylı olarak yapmışımdır. Üniversite dışında etkinliklerde üniversiteyi temsil etmeye çalışıyorum." (A9)

"Evet diye düşünüyorum, bizim kurumda herkes her zaman birbirine yardım etmeye hazırdır. Herhangi bir üzüntü veya sevincimizi hemen birbirimiz ile paylaşırız." (A15) 
"Bence yoktur. Çünkü insanın ve kurumun planları her an değişebilir. Önceden kendimi bu kurumun bir parçası olarak düşünüyordum, işten çıkarılan arkadaşları görünce kimsenin yerinin garanti olmadığını anladım. Hiç kimse vazgeçilmez değil, bu konu da artık böyle düşünüyorum" (A12)

"Evet çok güzel uygulamalarımı var, görevde yükselen veya kurumdan ayrilanlara yemekler veriyoruz, Yeni yıl kutlamasl, kadınlar günü vb. kutlamaları birlikte kutluyoruz. Bazen ev alan veya evlenen kişileri de hediye alarak evlerinde ziyaret ediyoruz." (A13)

"En azından beraber çalıştı̆̆ım kadınların örgütsel bağhlĭğının oluşmasında rolüm olduğunu düşünüyorum. Özellikle benden sonra işe başlayanlarla tecrübelerimi paylaşırken, öğretirken doğrudan olumlu etkilemekteyim." (A1)

"Bilmiyorum olabilir, çünkü bizim kurumda herkes birbirini çok seviyor ve arkadaşlar birbirini destek oluyor. Bu durumu diğer birimlerde dile getiriyor. İnşallah nazar değmez." (A14)

"Evet. Meslektaşlarımı her konuda destekliyor ve takım ruhu içinde çalışmalarına katkı vermeye çalışıyorum." (A10)

Değişik demografik özelliklere sahip olan katılımcıların bu soruya verdikleri cevapları da farklılaştırmıştır. Verilen cevaplar incelendiğinde kadın akademisyenlerin örgütsel bağlılığa yüksek derecede katkı sağladığı görülmektedir.

\section{SONUÇ VE ÖNERİLER}

Araştırma Kırgızistan-Türkiye Manas Üniversitesi'nde görev yapan kadın akademisyenlerin örgütsel bağlılıkla ilgili sorulara vermiş olduğu cevaplar ile sonuçlanmıştır. Araştırma kapsamında yer alan 16 katılımcının \% 81,25'i görev yapmış oldukları kurumda 10 yıldan fazla çalışmaktadırlar. Ayrıca çalışanların büyük bir çoğunluğu da akademisyenliği 10 yıldan daha fazla süredir yapmaktadırlar. Araştırma kapsamında yer alanların \% 87,50'si evli, geri kalanları ise bekârdır.

Araştırma sonucunda kurumlarda kadın akademisyenlere yönelik hiçbir yazılı kural ve politikanın olmadığı tespit edilmiştir. Kadınların kariyer başarısı kurum ve amirleri tarafından az da olsa desteklendiği belirlenmiştir. Bu durum kadın akademisyenler ile kurum arasında olumlu bir ilişkinin kurulmasına neden olmaktadır. Ayrıca kurum iklimi iyi olan işletmelerde örgütsel bağlılığın da olumlu yönde oluşacağı sonucuna ulaşılmıştır.

Araştırma kapsamında elde edilen veriler incelendiğinde amirin tutumu, örgütsel bağlllığın oluşmasında önemli etkiye sahip olduğu belirlenmiştir. Amirin konuşma üslubu, tutum ve davranışları örgütsel bağlllığı doğrudan etkilemektedir. Amirlerin bu şekilde olumlu bir kurum atmosferine katkı sağlaması sadece kadın akademisyenlerin değil, tüm personelin kariyer planlamasını başarıyla sonuçlandırır. Duygusal bağlılığa sahip olan personel kurum için değerlidir. Çünkü kuruma bağlı olan personelin işten ayrılma, devamsızlık yapma oranı oldukça düşüktür. Kendilerini kurumun ayrılmaz bir parçası olarak görür ve kendileri istedikleri için kurumda çalışmaya devam ederler. Elde edilen veriler incelendiğinde araştırma kapsamında yer alan tüm kadın akademisyenlerin bu duyguya sahip olduğu tespit edilmiştir.

Kurum içinde kadın akademisyenlerin kurumsal bağlllıklarının oluşabilmesi için birbirleriyle çok daha etkin iletişim ve işbirliği içerisinde olması gerekmektedir. Yönetim departmanı tarafından yapılacak grup içi çalışmalar, ekip ruhunun oluşmasına katkı sağlayacaktır. Böylelikle, akademisyenler birbirlerini daha yakından tanır, yardım ve destek paylaşımı yaparlar. Bu uygulama sonucunda sadece kadınlar arasında değil tüm çalışanlar arasında sağlıklı bir işbirliği oluşur ve iş performansı artar.

Örgütsel bağlılığın oluşmasında kadın akademisyenlerin kendi rolünü görebilmeleri için, öncelikle kurum içinde hoş bir atmosfer oluşturulması gerekmektedir. Bunun için yönetimin sorumluluk alması gerekir. Çünkü bu durum herkes için önemlidir. Ekip olarak ne kadar çok iş yapılırsa, çalışanlar birbirlerini daha yakından tanıyarak daha çok yardımlaşma duygusuna sahip olacaktır. Bunun sonucunda, herkesin az da olsa, örgütsel bağlılığın oluşmasına katkı sağlayacaktır.

Araştırma sonucunda Kırgızistan-Türkiye Manas Üniversitesi'nde görev yapan kadın akademisyenlerin görev yaptıkları kurumdaki amirler ve meslektaşlar arasında pozitif bir bağ ve ilişki bulunmaktadır. Ancak bunun oluşmasında kendilerinin çok az rollerinin olduğu belirtilmektedir. Çalışma sonucunda elde edilen veriler ve kullanılan yöntem örgütsel bağllıkla ilgili sadece kadın akademisyenlerin değil, erkek akademisyenlerin de rolünü belirlemeye yöneliktir. Buradan elde edilen nicel ve nitel veriler farklı işletmelerde benzer araştırmaların yapılmasına referans olabileceği öngörülmektedir. 


\section{KAYNAKÇA}

Bişgin, H. (2014). Examination of organizational commitment levels of physical education and sports teachers according to various variables (case study of Kutahya province). Turkish Journal of Sport and Exercise, 16(2), 89-96. doi:10.15314/TJSE.201428111

Bozkurt, Ö., \& Yurt, İ. (2013). Akademisyenlerin Örgütsel Bağlllık Düzeylerini Belirlemeye Yönelik Bir Araştırma. Yönetim Bilimleri Dergisi, 11(22), 121-139.

Dikmen, N., \& Maden, D. (2012). Kadın Akademisyenlerin Görünmeyen Emeği Üzerine Bir Araştırma: Ordu Üniversitesi Örneği. Sosyal ve Beşeri Bilimler Dergisi, 4(2), 235-250.

Doğan, S., \& Kılıç, S. (2007). Örgütsel Bağl1lı̆̆ının Sağlanmasında Personel Güçlendirmenin Yeri ve Önemi. Erciyes Üniversitesi İktisadi ve İdari Bilimler Fakültesi Dergisi(29), 37-61.

Gökdeniz, K., Erdem, H., \& Tikici, M. (2015). Cam Tavan Algısı İle Örgütsel Vatandaşlık İlişkisi: Yükseköğrenim Kurumlarında Görev Yapan Kadın Çalışanlar Üzerinde Bir Araştırma. Akademik Araştırmalar ve Çalışmalar Dergisi, 7(13), 125-144.

Güçlü, H. (2006). Turizm Sektöründe Durumsal Faktörlerin Örgütsel Bağlllk Üzerindeki Etkisi. Eskişehir: Turizm ve Otel İşletmeciliği Yüksekokulu Yayınları; no.9.

Klenke, K. (2011). Women in Leadership: Contextual Dynamics and Boundaries. Bingley, England: Emerald Publishing Group Limited.

Korkmaz, H. (2016). Yönetimde Kadın ve Cam Tavan Sendromu. Alternatif Politika(Toplumsal Cinsiyet Özel Sayıs1 II), 95-112.

Kozak, M. (2014). Bilimsel Araştırma: Tasarım, Yazım ve Yayın Teknikleri. Ankara: Detay Yayıncllı.

Liou, S.-R. (2008). An Analysis of the Concept of Organizational Commitment. Nursing Forum, 43(3), 116-125. doi:10.1111/j.1744-6198.2008.00103.x.

Mason, M. (2010). Sample Size and Saturation in PhD Studies Using Qualitative Interviews. Forum: Qualitative Social Research Socialforschung, 11(3).

Meyer, J. P., \& Allen, N. J. (1997). Commitment in the Workplace: Theory, Research, and Application (Advanced Topics in Organizational Behavior). Sage Publications.

Özdevecioğlu, M. (2003). Algılınan Örgütsel Destek ile Örgütsel Bağlllık Arasındaki İlişkilerin Belirlenmesine Yönelik Bir Araştırma. D.E.Ü.İ.I.B.F. Dergisi, 18(2), 113-130.

Suğur, S., \& Cangöz, İ. (2016). Üniversite Yönetiminde Kadınların Eksik Temsili Üzerinde Toplumsal İlişkilerinin Rolü. Amme İdaresi Dergisi, 49(3), 89-115.

Şentürk, B. (2015). Çokuz Ama Yokuz: Türkiye'deki Akademisyen Kadınlar Üzerinde Bir Analiz. ViraVerita E$\operatorname{Dergi}(2), 1-22$.

Ünlü, U. (2017). Kamu Kurumlarında Örgütsel Bağlllık Açısından Örgütsel Sadakatin Önemi. Sayıştay Dergisi(106), 147-162.

Yıldız, S. (2018). Türkiye'de Kadın Akademisyen Olmak. Yükseköğretim ve Bilim Dergisi, 8(1), 29-40. doi:10.5961/jhes.2018.245

Yüceler, A. (2009). Örgütsel Bağlılık ve Örgüt İklimi İlişkisi: Teorik ve Uygulamalı Bir Çalışma. Selçuk Üniversitesi Sosyal Bilimler Enstitüsü Dergisi(22), 445-458.

Zefeiti, S. M., \& Mohamad, N. A. (2017). The Influence of Organizational Commitment on Omani Public. International Review of Management and Maketing, 7(2), 151-160. 